International Journal of Agriculture, Environment and Bioresearch

Vol. 5, No. 05; 2020

ISSN: $2456-8643$

\title{
ECONOMICS ANALYSIS OF RICE PRODUCTION AND PROCESSING IN NIGERIA (1981 - 2019)
}

\author{
Akinniran, Taiwo Nuraeni And Faleye, Gloria Rolake \\ Department Of Agricultural Economics, faculty Of Agricultural Sciences, ladokeakintrola University Of \\ Technology, ,p. M. B. 4000, Ogbomoso, Nigeria \\ https://doi.org/10.35410/IJAEB.2020.5557
}

\begin{abstract}
The project examined and evaluated in comparative terms, the economics of rice production and processing in Nigeria using annual time series databetween 1981-2017. Specifically, it analyzed the trend in rice production and processing, discussed factors affecting rice productivity, determine rice production profitability and examine the factors limiting the processing of rice in Nigeria.
\end{abstract}

Secondary data were used for analyzing the data and data was collected from Central Bank of Nigeria Statistics and Food and Agricultural Organization (FAO). Dickey-Fuller unit root test and co-integration test were employed to analyze the data collected. The result shows that the time series used for the study are stationary at first difference. Some econometric tools were employed to explore the relationship between the variable specified in the model. The study examines the characteristics of each time series correlation is absent, then we adopted the cointegration/ECM test methods to determine the long-run relationship between the dependent and independent variables. .

The result of co-integration test in the short run Error Correction Model (ECM) estimation at 1 lag length shows that Local Rice Price (LRP), Population (POP), National Gross Domestic Product (GDP) are all significant at $1 \%$ to rice production. The result of the long-run ECM estimation shows that Population is significant at 5\%, local rice price and GDP are significant at $10 \%$. The coefficient of all the variables is positively related. Local rice price is positively related which shows increase in price leads to increase in production. The result of the trend shows that price of local rice is stationary at first difference and also positively related to rice production at both short-run and long-run ECM estimation which indicates that price of local rice time trend favours rice production and processing. This shows a positive sign that rice production and processing is positive and profitable due to the country used to importation of rice. Hence, government should support production and processing of rice in the country more than importation resulting in a decrease in the exchange rate and having a say on the price of exported products. It is therefore recommend that more agricultural product should be produce in the country and government should provide loan for rice farmer and purchase of rice processing equipment to improve production of rice

Keywords: Production, Rice, Price, External reserve, Importation. 
Vol. 5, No. $05 ; 2020$

ISSN: $2456-8643$

\section{INTRODUCTION}

Rice, Oryzasativa (Asian rice) or Oryzaglaberrima (African rice) is one of the world's most important cereals, Rice has become a staple food for over 50\% every household; both the rich and the poor consumes (Godwin, 2012). Rice is indispensable in the strategy for food security because it provides $27 \%$ of the energy and $20 \%$ of protein needs in developing countries, including African countries (Seck, 2007 and Tollens, 2007). Rice is among the three leading food crops of the world, with maize and wheat being the other two. All three directly provide no less than $42 \%$ of the world's required caloric intake. In 2009, human consumption was responsible for $78 \%$ of the total usage of produced rice.

Nigeria's fertile land and rich agro-climatic conditions could easily produce rice to feed the entire country and generate surplus. However, Nigeria has continued to depend on importation from countries like China and Thailand to meet the increasing demand for rice by household. A combination of various factors seems to have triggered the structural increase in rice consumption over the years with consumption broadening across all socioeconomic classes, including the poor. In a bid to achieve rice self-sufficiency in Nigeria, a rice transformation action plan was set up in 2011 under the umbrella of the Agricultural Transformation Agenda (ATA). (Frederic et al. 2003) observed that, with rice now being the structural component of the Nigerian diet, and rice imports making up an important share of Nigeria's agricultural imports, there is considerable political interest in increasing the consumption of local rice. This has made rice a highly political commodity.

Akpokodjeet al, (2001) maintained that, a comprehensive and up to date picture of rice sector in Nigeria in general and rice production, processing and consumption in particular is lacking. It can be seemingly noticed that, despite its agricultural potentials, Nigeria is yet to harness its vast land resources suitable for agriculture, but even to cater for its domestic consumption which will invariably serve for sufficient food security. This is evident from the fact that, rice consumption in Nigeria increases over decades and in alarming rates. Achieving self-sufficiency in rice production and processing is not a function of only planting large hectares of land with rice neither does it end at producing millions of tonnes of paddy rice. The quality and quantity of processed Nigerian rice available in the market and having the quality desired by consumers closes the rice import gap in the demand for imported rice brands to meet the shortfalls in domestic demand and to meet consumers demand in the urban areas. The cost of rice imports represents a significant amount of lost earnings for the country in terms of jobs and in agricultural import, there is considerable political interest in increasing the consumption of local rice. This has made rice a highly political commodity.

Akpokodjeet al, (2001) maintained that, a comprehensive and up to date picture of rice sector in Nigeria in general and rice production, processing and consumption in particular is lacking. It can be seemingly noticed that, despite its agricultural potentials, Nigeria is yet to harness its vast land resources suitable for agriculture, but even to cater for its domestic consumption which will invariably serve for sufficient food security. This is evident from the fact that, rice consumption in Nigeria increases over decades and in alarming rates. Achieving self-sufficiency in rice production and processing is not a function of only planting large hectares of land with rice 
neither does it end at producing millions of tonnes of paddy rice. The quality and quantity of processed Nigerian rice available in the market and having the quality desired by consumers closes the rice import gap in the demand for imported rice brands to meet the shortfalls in domestic demand and to meet consumers demand in the urban areas.

The cost of rice imports represents a significant amount of lost earnings for the country in terms of jobs and income (Bambaet al., 2010). The quality of imported rice is far better than the Nigerian produced rice and households are dissatisfied with Nigerian rice bought in the market and are weary of picking stones from the Nigerian rice and having to wash it several times. Out of the thirty six states in Nigeria, only eight States can produce rice in a large scale. These states include: Anambra, Nassarawa, Ebonyi, Kaduna, Niger, Kano Kaduna and Benue. According to the Nigeria rice production statistics, Nigerian rice importations have made up 50\% of the local consumption rates. Currently, Nasarawa State is the leader when it comes to rice production in Nigeria. It has over 10,000 fully irrigated rice hectares. Rice consumption has risen tremendously at about $10 \%$ per annum due to changing consumer preferences. However, most Nigerians prefer to consume imported rice brands as compared to local rice varieties. The reason is that most Nigerian rice processors lack adequate technology of rice processing to meet international standard. FAO's forecast of world rice inventories at the close of 2017/18 marketing season.

Currently, Nigeria is one of the largest importers of rice in the world. The high importation of rice in Nigeria can be traced to rapid increase in population and also the demand for it by many Nigerians in their diets. Nigerian population is expected to be growing annually which implies that there will be increase in demand for rice. Milled rice is widely consumed in Nigeria as household food item and it is also being used by industries to produce other rice-based food and pharmaceutical products. Thus, the major industrial rice consumers in Nigeria are food and drink industries (for example, pasta and bread industries, beer and other liquor distilleries), and pharmaceutical companies.

In 2016, national rice demand was estimated at 6.3 million metric tons while domestic supply was put at 2.3 million metric tons. The deficit of 4 million metric tons was expected to be filled by import. Importation of rice is detrimental to Nigeria's economy because it portends a serious danger in terms of foreign exchange (forex) earnings and its depletion of the nation's foreign reserves. In order to bridge the gap between supply and the ever growing demand; the federal government of Nigeria, at one time or the other, has initiated policies and incentives for farmers to increase rice production locally. One of such policies is the 2006 presidential initiative on accelerated rice production, which was targeted at, reducing the import and developing of local rice industry and put a 50 percent duty on parboiled rice. In addition, a levy of ten percent was imposed on rice imports to create a dedicated fund for the development of the local rice industry, including processing and marketing. Considering the importance of rice as a popular menu on the table of many Nigerians and the income it generates for those who cultivate it, this critically assesses the impact of continuous rice importation on Nigeria's economy and how this negative trend can be reversed through the various opportunities that are available in the rice sub-sector.

Parboiled rice, considering the importance of rice as a popular menu on the table of many Nigerians and the income it generates for those who cultivate it. Nigeria's rice sub-sector is 
Vol. 5, No. $05 ; 2020$

ISSN: $2456-8643$

dominated by weak and inefficient producer-market linkages due to lack of production, technical know- how, poor infrastructure including lack of improved processing facilities, low rice productivity, poor post -harvest handling and storage, expensive and poor access to inputs (high quality seed, fertilizer, and crop protection product).

Majority of rice production and processing in Nigeria is in the hands of resource poor subsistent farmers who lack the economic and social power to fully adopt technologies. Availability of a sustainable rice processing technology for Nigerian resource-poor rice farmers is important if the country's effort at achieving self-sufficiency in rice production must be achieved. However, generating agricultural technologies is meaningful only when they are adopted at the farm level. Research institutes (IITA and NCRI) introduced varieties that will produce higher yield in order to boost food security. Some improved high yielding rice varieties released for utilization in Nigeria are FARO 35 and ITA (212) which are all lowland varieties.

Nigeria is ecologically endowed to attain self-sufficiency in paddy rice production with potential land area for rice production of between. However, in spite of the immense untapped potential in rice production in Nigeria and very favourable ecologies for rice production in Nigeria, production of paddy rice remains low.

Over 90 percent of domestic rice production comes from resource poor and weakly organized smallholders. These smallholders apply a low-input strategy to agriculture, with minimum input requirements and low output (International Fund for Agricultural Development [IFAD], 2009). The livelihood of these smallholder farmers have been constrained by a host of challenges such as low productivity, paucity of opportunities for value addition, limited access to productive assets and inputs, inadequate support services (extension and research), inadequate market and rural infrastructure, post-harvest losses and a constrained enabling environments. More so, a huge proportion of domestic rice in Nigeria is not tailored to meet market needs. This has also limited the market share of the domestic rice producer.

Nigeria is one of the major rice producing areas and market for locally produced rice. This makes it a reference point for rice production in Nigeria. There is prevalence of rice farmers adopting different production systems. However, there is still dearth of information on the extent of value addition as well as profit margins in rice production in Nigeria.

Nwaobiala and Adesope(2015) analyzed the economics of smallholder rice production systems in Nigeria. They compared the net profit between upland and swamp rice farmers and assessed the Protection and Comparative Advantage in Rice Processing in Nigeria, They determined the contributors to value-addition in the processing of paddy rice into basic milled rice and valueadded rice and asserted that the margin derivable from the processing of paddy rice into basic milled rice per ton was lower compared to further processing of basic milled rice into value added rice per ton. From ongoing the study was designed to examine the economics analysis of rice production and processing in Nigeria. Specifically, it was designed to: analyse the trend in rice production and processing, discuss the factors affecting rice productivity, determine rice production profitability and examine the factors limiting the processing of rice in Nigeria. The hypothesis was state in null form as: Rate of rice production is not price determinant 
Vol. 5, No. $05 ; 2020$

ISSN: $2456-8643$

\section{Rice production}

Despite the fact that rice is cultivated almost all the ecological zones of Nigeria, yet its sustainability to mankind still remain small. In 2000, out of about 25 million hectares of land cultivated to various food crops, about $6.37 \%$ was allocated to rice production. Rice was grown on approximately 3.7 million hectares of land in Nigeria. Rice production in Nigeria is dominated by smallholder farmers who use traditional methods that are characterized with problems of low productivity (Tsadoet al. 2014). Productivity increase in the four decades is centered on increasing the number of new varieties and a positive and increasing trend in the rate of adoption of modern varieties (simtoweet al. 2012). Though increase may not wholly be attributed to varietal improvement, their steady increase in rice production in the past four decades provide further evidence that there is potential for further improvement in productivity (simtoweet al. 2012). It is believed that the access to and adoption of improved rice seed varieties would go a long way in raising the productivity of small - scale rice farmers and consequently improve their livelihood. According to (Adekambiet al. 2009), productivity increase in agriculture has the capability of reducing poverty through increase in farmer's income and reduction in using local farm tools. Nigeria has four rice production systems namely: upland rice, lowland rice, irrigated rice and mangrove/deep water rice production system. The international rice market is highly stratified by type and quality thus leaving little room for substitution. There are many varieties of rice and the different varieties are not considered interchangeable, either in processing or in production, with the result that each variety commands a separate market from other varieties. It is common for one variety of rice to rise in price while another one drops in price (USDA, 2000). The four main types of rice; Indica, Japonica, aromatic, and glutinous, has individual stratified levels of quality. This stratification further adds to the thinness, price volatility, and uncertainty since due to numerous rice varieties and standards of quality, there is no generally accepted world market price for rice (Pesticide Action Network Asia \& the Pacific, 2008). Many SSA countries have made significant strides towards increasing their rice production by encouraging the adoption of new and improved varieties but mostly through area expansion and extensification. Initiatives currently underway in several countries - most significantly in Nigeria- are contributing to what is likely to become a trend of increasing production in SSA. Sustained high prices for rice in the international markets will bolster these initiatives. West Africa remains the hub of rice production in Sub-Saharan Africa but the shortfall in rice production has increased significantly, as consumption rises at a rate well above that of production growth (Africa Rice, 2007).

In addition to the gap in farming system technology and knowledge, many rice grain producing countries have significant post-harvest losses at the farm. This is because of poor roads, inadequate storage technologies, inefficient supply chains and farmer's inability to bring the produce into retail markets. A World Bank - FAO study claims $8 \%$ to $26 \%$ of rice is lost in developing nations, on average, every year, because of post-harvest problems and poor infrastructure (World Bank, 2011a). (Basavaraet al, 2007) claim the post-harvest losses exceed $40 \%$. In Nigeria, rice can be grown in different environments, depending upon water availability. Different rice production systems in Nigeria depend on the ecology and vary in terms of yield per cropped area. The difference between potential and actual yields is very high. However, there is conflicting information on average yields from different sources. (Africa Rice, 2011) reports that in 2008 Nigeria had an increase in rice production of 31.2\%. In 2012, Africa Rice conducted 
a diagnostic and yield gap survey to identify the causes of yield gaps and challenges in rice production.

A diagnostic survey involves interviews with individual farmers or other actors such as input suppliers and extension workers, and group discussion to understand farmers' current practices, knowledge and the challenges and constraints they face. A yield-gap survey involves interviewing farmers, a series of field observations from sowing to harvesting, soil and plant sampling, and yield measurement (Africa Rice, 2013). These two surveys enable the measurement of on-farm yields obtained by farmers and potential yields, which can be determined by crop simulation models and their causes.

The major challenges identified from the survey include; weed infestation, lack of availability of purified seeds of new, improved varieties and lack of mechanization. Others include; sub-optimal crop and nutrient management, including timing of interventions in irrigated systems, suboptimal land preparation and water management in rain fed lowlands, and droughts and soil problems in uplands (Africa Rice, 2013). Causes of yield gaps in farmers' fields vary among rice production systems and agro-ecological zones (Africa Rice, 2013). But, typical causes include sub-optimal crop management, yield limiting (e.g. poor soils) and yield-reducing (e.g. pests), factors, socio-economic constraints (e.g. finance, labour shortage) and institutional/ political arrangements (e.g. land availability, rice and fertilizer prices).

Rice Cultivars and harvesting in Nigeria

Rice cultivars are often classified by their grain shapes and texture. High-yield cultivars of rice suitable for cultivation in Africa and other dry ecosystems have been developed. It is hoped that their cultivation will improve food security in West Africa. A wide variety of improved seeds are available in Nigeria, produced by the National Cereals Research Institute, often in conjunction with the West Africa Rice Development Association (WARDA). The varieties are widely known, from NERICA (the New Rice for Africa, developed in the 1990s) to Nigerian varieties that offer a range of characteristics around length of growing season, size of the grain, water requirements, etc. Farmers generally use a seed that is adapted to their conditions (USAID, 2009).

The biggest challenge is to get farmers to purchase new seeds on a regular basis, reinvigorating their productive potential, rather than planting old seeds that have lower yields. The use of mechanized soil preparation is limited primarily to farms that are larger than 2 hectares, or are part of a larger production system conducive to mechanized plowing (such as most of the irrigation schemes). Smaller farms tend to be fragmented and difficult to plow mechanically. Additionally, the high cost of tractor services makes it just as economical for small farms to prepare the land by hand. There is strong potential to increase productivity if the right conditions are in place. The process of collecting the mature rice crop from the field is called harvesting this can be done manually or mechanically. Depending on variety, a rice crop usually matures between 115 and 120 days after establishment (activities include cutting, stacking, handling, threshing, cleaning and hauling). Good harvesting methods help maximize yield and minimize damage and deterioration. Manual harvesting is common in Africa and Asia and involves cutting the rice crop with simple hand tools like sickles and knives: this requires between 40 and 80 person-hours per hectare plus additional labour to manually collect and haul the crop. Mechanical harvesting - using reapers or combine harvesters - is not so common due to the unavailability and high cost of machinery. The key steps involved in rice production (IRRI 2012) 
Vol. 5, No. 05; 2020

ISSN: $2456-8643$

are:

Seed selection: Choosing a variety suitable to the environment it will be grown in and ensuring the seed of that variety is of the highest quality is the first essential step in rice production. Land preparation: The aim of land preparation (ploughing and harrowing) is to get the soil in the best physical condition for crop growth and to ensure the surface is level to reduce water wastage.

Crop establishment: The two main practices of establishing plants are transplanting and direct seeding.Water management; Rice is extremely sensitive to water shortages, so sound management practices are needed to use water wisely and maximize yields. Nutrient management: Good management of the soil nutrient is needed for optimal yield. Crop Health: Rice has a wide array of 'enemies' that must be managed including rodents, harmful insects, viruses, diseases and weeds with the last being controlled by the hoe or chemicals. Threshing: Following harvesting, rice must be threshed (to separate the grain from the stalk) and cleaned (this can be done by hand or machine).

Postharvest: After harvest, the rice grain (paddy) undergoes a number of processes include drying, storing, milling and processing: Drying is the process that reduces the grain moisture content to between 18 and 22 percent, which makes it safe for storage. Drying is outside on mats, making use of sunshine or artificially heated air. Drying is the most critical step after harvesting. For a rice crop; delays, incomplete or ineffective drying reduce grain quality and quantity.Milling is a crucial step in the postharvest process, the basic objective being to remove the husk and the bran layers and produce an edible, white kernel that is free from impurities.

\section{Rice Processing}

Paddy rice is harvested when the grains have a moisture content of around $25 \%$. In Nigeria where rice is almost entirely the product of smallholder agriculture, harvesting is carried out manually, although there is a growing interest in mechanical harvesting. Harvesting can be carried out by the farmers themselves or by hired labour. Harvesting is followed by threshing, either immediately or within a day or two. Subsequently, paddy needs to be dried to bring down the moisture content to no more than $20 \%$ before threshing and milling.

In some cases, the paddy rice is parboiled before milling. Parboiling is the hydrothermal treatment of paddy before milling. It involves soaking the paddy in water for about 30 minutes, heat treating the wet paddy by steam, and drying the paddy to safe moisture content. In Ebonyi State, the parboiling process is carried out manually using drums. Parboiled rice is dried on mats by roadside. Milling involves the removing the edible, white rice kernel that is sufficiently milled and free of impurities. The milled can further be processed by picking out the stones manually or using destoner (a machine that separates the rice grain from the stones). Other processing activities include polishing, sorting, grading, packaging and branding. All these activities add value to final product.

\section{Consumer Demand}

The demand for rice in Nigeria has been soaring at a very fast rate over the years. A combination of various factors seems to have triggered the increase in rice consumption. According to (Akanji 1995), rising demand was partly the result of increasing population growth. Also increased income levels following the discovery of crude oil led to a rise in the demand for the commodity. The most important factor contributing to the shift in consumer preferences away from 
Vol. 5, No. $05 ; 2020$

ISSN: $2456-8643$

traditional staples and toward rice is rapid urbanization and associated changes in family occupational structures. As women enter the work force, the opportunity cost of their time increases and convenience foods such as rice, which can be prepared quickly, rice is importance similarly, as men work at greater distances from their homes in the urban setting, more meals are consumed from the market where the ease of rice preparation has given it a distinct advantage. These trends have meant that rice is no longer a luxury food but has become a major source of calories for the urban poor. Average Nigeria now consumes $34.8 \mathrm{~kg}$ of rice per year, representing 9\% of total caloric intake (Rice Web, 2001).

\section{Policies on Rice Production in Nigeria}

The Nigerian government had at various times enacted policies aimed at increasing rice production, make the nation self-sufficient and meet domestic demand for rice in Nigeria. A number of key policies and investment strategies had been introduced to reduce imports and increase the competitiveness of local rice. This is being done through a combination of import restrictions, input policy and institutional reforms, and investments across the rice value chain (Johnson, et al., 2013). However, the country's policy on rice has been inconsistent and has oscillated between import tariffs and import restrictions including outright ban (Emodi\&Madukwe, 2012). According to (Coulter and Havrland, 2005), seeking to eliminate imports over a short-time span is very unrealistic with consumption outstripping production. Growth in rice demand as a preferred staple, is so strong that production intensification and higher yields per ha has not been sufficient to fill the gap and meet rice demand (Tollens, 2007). Extensification or a rapid increase in the area under rice cultivation (irrigated and rain fed) was recommended. From historical perspective, rice policies and acts in Nigeria can be discussed under three periods (Akande, 2003). These are

Pre-ban period (1971-1985): This can be classified into pre-crisis (1971-1980) and the crisis period (1981-1985). The Pre-Crisis period was largely characterized by liberal policies (agricultural policies, programs, projects and institutions) on rice imports. Ad-hoc policies were put in place during times of interim shortages. It corresponded to the launching of various programmes and projects aiming at developing rice production. During the crisis period, more stringent policies (Input Supply and Distribution Policy, Agricultural Input Subsidy Policy, Water Resources and Irrigation Policy, Agricultural Cooperatives Policy) were put in place. Government policies artificially lowered domestic rice and fertilizer prices relative to the world price level, through massive importation of rice resulting in low price of locally produced rice. Government was involved in rice importation, distribution, and its marketing with non-transfer of actual costs to consumers.

Ban period (1986-1995): The ban placed on rice import was reinforced by the introduction of Structural Adjustment Programme (SAP) in 1986. Under SAP, various trade policies (tariff, import restrictions, and outright ban on rice import at various times) were put in place. It was illegal to import rice into the country, though importation of the commodity through the country's porous borders thrived during this period.

Post-ban period (1995-2011): During this period restrictions on rice importation were lifted, with more liberal trade policy put in place. The decline in domestic rice production cannot all be blamed on increasing rice imports. A number of reasons led to the lifting of the ban. There was extended pressure from the international financial organizations, such as the World Bank, World 
Vol. 5, No. $05 ; 2020$

ISSN: $2456-8643$

Trade Organization, and the International Monetary Fund (IMF).who argued that the ban on rice was not in consonance with the liberalization position of the government. On the domestic scene, the government failed in the implementation of the ban on the commodity. This is evidence by the major markets in Nigeria flooded with imported rice despite restrictions. There was also pressure on the government by those who had vested interest in rice importation and the urban elites who had a preference for the consumption of imported rice (Ladebo, 1999).

\section{Agricultural Transformation Agenda, ATA (2011-2015)}

In 2011, Nigerian government embarked on a plan to make the country self-sufficient in rice production by 2015 under its Agricultural Transformation Agenda (ATA). This was in response to the perceived threat of huge volumes of rice importation into Nigeria every year with an import bill that exceeds US $\$ 2$ billion (Johnson, et al., 2013). The reforms include deregulating seed and fertilizer markets and setting up private-sector marketing corporations to help coordinate the market and set grades and standards. Innovative financing mechanisms for supplying credit were also being pursued while physical investments were made to establish staple crop processing zones (SCPZ) that were intended to encourage the clustering of food processing industries in proximity to raw materials and end markets (Johnson, et al., 2013). The overall goal of the Agenda is to define agriculture as a business, promote private sector investment in agriculture, along with the development of private sector driven marketing organizations and the promotion of Incentive-based Risk Sharing for Agricultural Lending (NIRSAL). NIRSAL is a dynamic, holistic approach that tackles both the agricultural value chain and the agricultural financing value chain. NIRSAL does two things at once; fixes the agricultural value chain, so that banks can lend with confidence to the sector, and encourages banks to lend to the agricultural value chain by offering them strong incentives and technical assistance. The goal of NIRSAL is to trigger an agricultural industrialization process through increased production and processing to boost economic earnings across the value chain. Unlike previous schemes, it encouraged banks to lend to the entire spectrum of the agricultural value chain and toall sizes of producers.

\section{Rice Value Chain in Nigeria and Constraints}

The main actors in the rice value chain in Nigeria are farmers, paddy traders, millers, rice traders and retailers. The main value adding activities include; harvesting, storage and paddy aggregation at traders' level, parboiling, milling, wholesaling, and retailing (Cadoni\&Angelucci, 2013).Rice farmers can be categorized in three main typologies: (1) smallholders applying a low input strategy (this represents majority of producers in the country) with low-yield and average of 2.0 hectares; larger-scale commercial farmers often providing first processing; and smallholder contract/out grower farmers adopting enhanced production technologies (USAID, 2009). The value chain for domestically produced rice in Nigeria is currently dominated by a largely fragmented production and milling industry, with limited new investment in either production or processing (USAID, 2009). While the returns are quite high at each stage of the traditional value chain channel, there are so many participants in the channel that the benefits are spread very thin and few have any incentive to invest. With very high prices, a protected market and ever-increasing imports, the potential is high to promote a strong supply response under the right conditions.( USAID, 2009) reports that new investments in heavier milling capacity in new 
channels offers good private-sector driven models that can compete with imports for the highend urban market, offer lower prices to consumers, yield high profit margins to both the producers and the millers and contribute to a more efficient value chain that improves food security in Nigeria. The rice value chain (processing and distribution sector) faces a number of key constraints in Nigeria. Milling technology is often outdated, resulting to high levels of broken rice. Millers are fundamentally constrained by lack of working capital that limits their ability to purchase paddy from farmers and update machinery. This contributes to the unofficial export of paddy to regional markets which prevents the country from capturing the value adding from rice milling. The lack of capital also perpetuates the low levels of technology implicit in the sector. High costs in the provision of credit dampen private investment by farmers and millers, forcing farmers to seek unofficial sources of credit from money lenders, often at usury interest rates, and millers to delay or reduce investments. Institutional and infrastructural constraints also impede the sector. Poor infrastructure, in the form of roads and irrigation dampen production incentives and reduce market access. These unnecessarily raise the costs of rice for consumers and lower the competitiveness for an export market. The primary objective of Nigeria's initiative on rice is to enhance household food security and income, eliminate import and generate exportable surplus.

\section{Consumption}

Currently, Nigeria is one of the largest importers of rice in the world. The high importation of rice in Nigeria can be traced to rapid increase in population and also the demand for it by many Nigeria in their diets. Nigerian population is expected to be growing annually which implies that there will be increase in demand for rice .Also, the share of rice in Nigerians diet increased from $1 \%$ in 1960 to $7 \%$ in 1980 and $15 \%$ in 2000 . Milled rice is widely consumed in Nigeria as household food item and it is also being used by industries to produce other rice based food and pharmaceutical products. Thus, the major industrial rice consumers in Nigeria are food and drink industries (for example, pasta and bread industries, beer and other liquor distilleries), and pharmaceutical companies. Different categories and grades of rice are widely consumed all over Nigeria. Imported rice has become more popular and some of this rice is imported from Thailand. In most urban areas in Nigeria, imported rice is largely consumed by a lot of people while locally milled rice is consumed largely by rural dwellers especially by those who cannot afford to buy foreign milled rice. Rice consumption varies from culture to culture in Nigeria. In most parts of Northern Nigeria, rice is used to prepare a special dish known as "tuwo" while in most areas in Southern Nigeria, rice is consumed as" jollof" ( rice cooked with spiced tomato puree) or fried or is boiled and served with stew. Other popular rice dishes in the country includes coconut rice (rice cooked or prepared with coconut), 'masa' (a fried dough made from local rice flour and water) mainly in the northern part of the country.

\section{Storage}

Rice should be store in cool, dry rodent-proof condition, until the grain is required to be milled for sale or for household consumption. Good storage reduces loss due to weather, moisture, rodents, birds, insects, microorganisms and theft. Storage add value by improving the quality of 
grains which increase consumer demand their by command high market value. Rice should be stored in airtight containers or in jute bags.

\section{Marketing}

Rice marketing is the performance of all business activities in the flow of paddy and milled rice, from the point of initial rice production until they are in the hands of the ultimate consumers at the right time, in the right place and as convenient as possible, at a profit margin so as to keep the farmer in his farming operation (Ihene, 1996). Marketing of local rice are divided into four stages with a change of product ownership occurring between each pair of stages. The first stage is production through harvesting. Stage two include movement from the farms to processing centres while stage three consist of moving the milled rice from processing areas to urban consumption centres. The fourth stage encompasses whole sailing and retailing in the urban centers. Marketing make rice available to both rural and urban dwellers through marketing channel, transportation is also important in marketing of rice, without transportation rice cannot be evenly distributed throughout the nation.

\section{Methodology}

The study was carried out in Nigeria. Nigeria is located in West Africa between latitudes 40and $140 \mathrm{~N}$ and between longitude 30 and 150E. It is bounded to the north by the Niger Republic and Chad, in the west by Benin republic, in the east by Cameroon Republic and the south by the Atlantic Ocean. Its capital is Abuja. Nigeria is divided into six geo-political zones with thirty six (36) States and one Federal Capital Territory. Nigeria consists of 774 Local Government Areas, the primary (third-tier) unit of government in Nigeria. Nigeria is often referred to as the "Giant of Africa", owing to its large population and economy. With 205 million inhabitants, Nigeria is the most populous country in Africa and the seventh most populous country in the world. Nigeria has the third-largest youth population in the world, after India and China, with more than 90 million of its population under age 18. The country is viewed as a multinational state as it is inhabited by 250 ethnic groups, of which the three largest are the Hausa, Igbo and Yoruba, these ethnic groups speak over 500 different native languages and are identified with a wide variety of cultures. Nigeria is a country in Africa with an area of $923,768 \mathrm{kmsq}$. Currently the country has a population of 203,315,891 people. Nigeria like the rest of West Africa and other tropical lands has only two seasons. These are dry season and rainy season. The dry season is accompanied by a dust laden air mass from the Sahara Desert, locally known as Harmattan while the rainy season is heavily influenced by an air mass originating from the South Atlantic Ocean, locally known as the South Western wind. Dry season on the other hand starts from late October and last until early March with peak dry conditions between early December and late February. Traditionally, Nigerians were predominantly subsistence farmers of sorghum, maize, millet, rice cassava, yams and plantains, however due to a lack of investment in technology, infrastructure, roads and marketing, agriculture has failed to keep up with the growth in the population. Hunting is another traditional occupation and bush meat is a delicacy often sold by the road side on the motor ways and markets all over the country. Fishing used to be another common occupation in the past among locals who live in the delta areas. Grass Weaving is still popular in the northern parts of the country, where grass which is abundant is woven into baskets, mats, tables and fans. Others occupation include carpentry, bronze and metal casting, pottery, cloth weaving and palm wine 
Vol. 5, No. $05 ; 2020$

ISSN: $2456-8643$

tapping.

Rice processor and rice producer constitute sample frame for this study.The study employs time series secondary data collected on the variables specified in the model, spanning the period between 1981-2017 from AGROSTAT Bulletins which include National Bureau of Statistics (NBS), International Institute of Tropical Agriculture (IITA), International Rice Research Institutes (IRRI), Central Bank of Nigeria's (CBN) economic and financial review and an online database maintained by Food and Agricultural Organization (FAOSTART).

The data collected were analyzed through the use of the unit root, co-integration test and regression analysis.If a time series has a unit root, it shows a systematic pattern that is unpredictable. A unit root attempts to determine whether a given time series is consistent with a unit root process. i.e. it is used to test for stationarity ( a stochastic process whose joint probability distribution does not change when shifted in time i.e. to determine whether the statistical properties such as mean, variance etc. are constant and do not change over time) or non- stationarity under time series variable. Studies in the previous indicated that time series data for Rice production, Exchange rate, Price of Local rice, Price of Imported rice, National GDP, External reserve and Population are likely to be non-stationary and according to Engle and Granger (1987) using data series that are not stationary for statistical analysis often result in spurious regression (i.e. a mathematical relationship in which two or more events or variables are not causally related to each other, yet it may be wrongly inferred that they are, due to either coincidence or the presence of a certain third unseen factor called a confounding factor or a lurking variable not apparent at the time of examination. It is a false presumption that two variables are correlated when in reality, they are not).Hence, to overcome this, the data were examined for stationarity (i.e. test for stability) using the Augmented Dickey Fuller (ADF) test developed by Dickey and Fuller in 1979, which is used to test for a unit root in a time series sample or autoregressive model.

Co-integration is said to exist between non -stationary variables if their linear combination, namely the residual of co-integration regression are stationary (Granger 1986) i.e. it establishes the stationarity of the residuals generated from running a static regression at a level of the independent variable on the dependent variables. This test will help to identify whether there is causality between the variables under consideration. This study employs the co-integration and Error correction Model (ECM) in analyzing the data, and the test is carried out to determine the long run relationship between the independent variable when one or more of the variables are non- stationary at a level which means they have a stochastic trend (Johansen, 1991) or to check if the independent variable can predict both at present (short-run) or future long-run.

Two sets of variables were used for this study: Dependent variables and the Independent variables. The dependent variable was rice production while the independent variables were the factors affecting the rice production and processing in the area of study. Regression analysis was used to analyze the factors affecting rice production in the study area. The equation was expressed as;

$\mathrm{Y}=\mathrm{f}(\mathrm{a}, \mathrm{X} 1, \mathrm{X} 2, \mathrm{X} 3, \mathrm{X} 4, \mathrm{X} 5, \mathrm{X} 6, \mu)$ are the coefficients

Where; 


$$
\begin{aligned}
& \mathrm{Y}=\text { Rice Production } \\
& \mathrm{X} 1=\text { Exchange Rate } \\
& \mathrm{X} 2=\text { Imported Rice Price } \\
& \mathrm{X} 3=\text { External Reserve } \\
& \mathrm{X} 4=\text { Population } \\
& \mathrm{X} 5=\text { Local Rice Price } \\
& \mathrm{X} 6=\text { National Gross Domestic Product } \\
& \mu=\text { Error term }
\end{aligned}
$$

The following production functions were explicitly fitted to the model:

Linear function: $\mathrm{Y}=\beta 0+\beta 1 \mathrm{X} 1+\beta 2 \mathrm{X} 2+\beta 3 \mathrm{X} 3+\beta 4 \mathrm{X} 4+\beta 5 \mathrm{X} 5+\beta 6 \mathrm{X} 6+\mu$ The presence of the error term $(\mu)$ took care of other variables that have an influence on rice production but are not stated in the model specified.

\section{RESULT AND DISCUSSION}

Rice demand increased every year as a result of increased in population growth and people had abandon the consumption of local rice for imported rice, and this lead to importation of rice from other countries. People prefer imported because it does not require processing while cooking and it saves time. Rice production (fig 1) show that in year 1981 rice production falls but with a gradually increase and rise sharply in year 2016.

The local price of rice shows the price of a metric ton of rice per US Dollars in Nigeria and this varies depending on the exchange rate. Local price graph (fig 2) shows that year 2008 has the highest price of local rice depending on the rate of exchange while local rice price rise and falls continuously over the years but with a gradual increase from 1990 till 2005.

A foreign exchange rate is the relative value between two currencies. The exchange rate is defined by how much money or amount of foreign currency that you can buy with one US dollars. The exchange rate defines how many Naira you can get for one US dollar. Exchange rate graph (fig 3) reveals that there is a regular flow in the exchange rate from year 1991 to 2017 and it gradually increases from 1995 to 2012 and a fast increase from 2014 to 2017.

Foreign external reserves are assets held on reserve by a central bank in foreign currencies which include bonds, treasury bills and other government securities. The most important reason for external reserve is to manage their currencies value. External reserve graph (fig 4) revealed that from year 1991 to 2004 has ups and down in the flow but rises from 2005 to 2008 and irregular flow from 2009 to 2017.

Population is the group of individual living together in a particular area over a period of time. The population grows steady in under-developed country. The graph (fig 5) shows that since 1981, the population of the country keeps growing and it multiplies by two after 28 years. It reveals the population is increasing year by year in a high rate.

The results presented in Table showed the stationary (unit root) test conducted for all the variables. Rice importation related properties were firstly analyzed in order to analyses rice importation in Nigeria. Dickey-Fuller was used to ensure that no error free in the data used or correlation in the data. Dickey-Fuller estimation is based on Ordinary Least Square (OLS). When rice production related properties were first tested, none is stationary at Level except the Population, meaning others are non-stationary at level which leads to further test. After further 
test, others are stationary at first difference. When all variables were differenced, the result of the unit root test indicated that the null hypothesis of non-stationary was rejected and therefore, the alternative is accepted. This means that all rice production properties used is in line with rice production and they exhibit possibility of moving together in the long-run. The table showed the critical value at $5 \%$. We need to note if the absolute value of the Dickey-Fuller test is lower than $5 \%$ critical DF statistic, the null hypothesis of non-stationary is rejected.

\section{Engel-Granger two-step ECM estimation}

The result presented in table 4.2 below shows the short run ECM estimation for rice production. Rice produced in Nigeria is the dependent variable and it is run against its independent variables which are Exchange rate (Ex rate), Local Rice Price (LRP), External Reserve (Ex Rsv), Population (POP) and National GDP (N. GDP).The result showed the Local Rice Price, Population and National Gross Domestice Product is significant at $1 \%$. The result showed that LRP, POP and GDP were significant to rice production but other variables (Ex rate and Ex Rsv) were not significant to rice production in the short run. Exchange rate is positively related to rice production in Nigeria which implies that an increase in exchange rate will lead to increase of 0.0522365 in rice produced. Local rice price is positively related to rice production in Nigeria. It's indicating that an increase in local rice price will lead to 0.4735737 increase in the rice produced. External reserve is negatively related to production of rice in Nigeria meaning an increase in external reserve will lead to likely a decrease of 0.0694682 of the rice produced. Population is positively related to rice production in Nigeria. This indicates that an increase in population will probably lead to increase of 3.17278 in rice produced. National GDP is negatively related to production of rice in Nigeria which means increase in National GDP will lead to 0.2031239 decrease in the rice produced.

\section{The Long-run ECM model Estimation}

Table below shows the long run ECM estimation for rice production in Nigeria. Rice production is run against its independent variables which are Exchange rate (Ex rate), Local Rice Price (LRP), External Reserve (Ex Rsv), Population (POP) and National GDP (N. GDP). The result showed that Local Rice Price and GDP are significant at $10 \%$ and Population is significant at $5 \%$. The result showed that LRP, GDP and POP were significant to rice production. Exchange rate is positively related to rice production in Nigeria which implies that an increase in exchange rate will lead to increase of 0.1695335 in rice production. Local rice price is positively related to rice production in Nigeria. It's indicating that an increase in local rice price will lead to 2.182777 increase in the rice production. External reserve is positively related to production of rice in Nigeria meaning an increase in external reserve will lead to likely an increase of 0.00375599 of the rice produced. Population is positively related to rice production in Nigeria. This indicates that an increase in population will probably lead to increase in110.8079 rice produce. National GDP is positively related to production of rice in Nigeria which means increase in national GDP will lead to 0.879866 increase in the rice production. This shows that Exchange rate and External Reserve were not significant and other variables, Local Rice Production, Gross Domestic Product and Population are significant and positively related to rice production which leads to the acceptance of the alternative hypothesis and rejection of the null hypothesis in the long run. 
International Journal of Agriculture, Environment and Bioresearch

Vol. 5, No. 05; 2020

ISSN: $2456-8643$
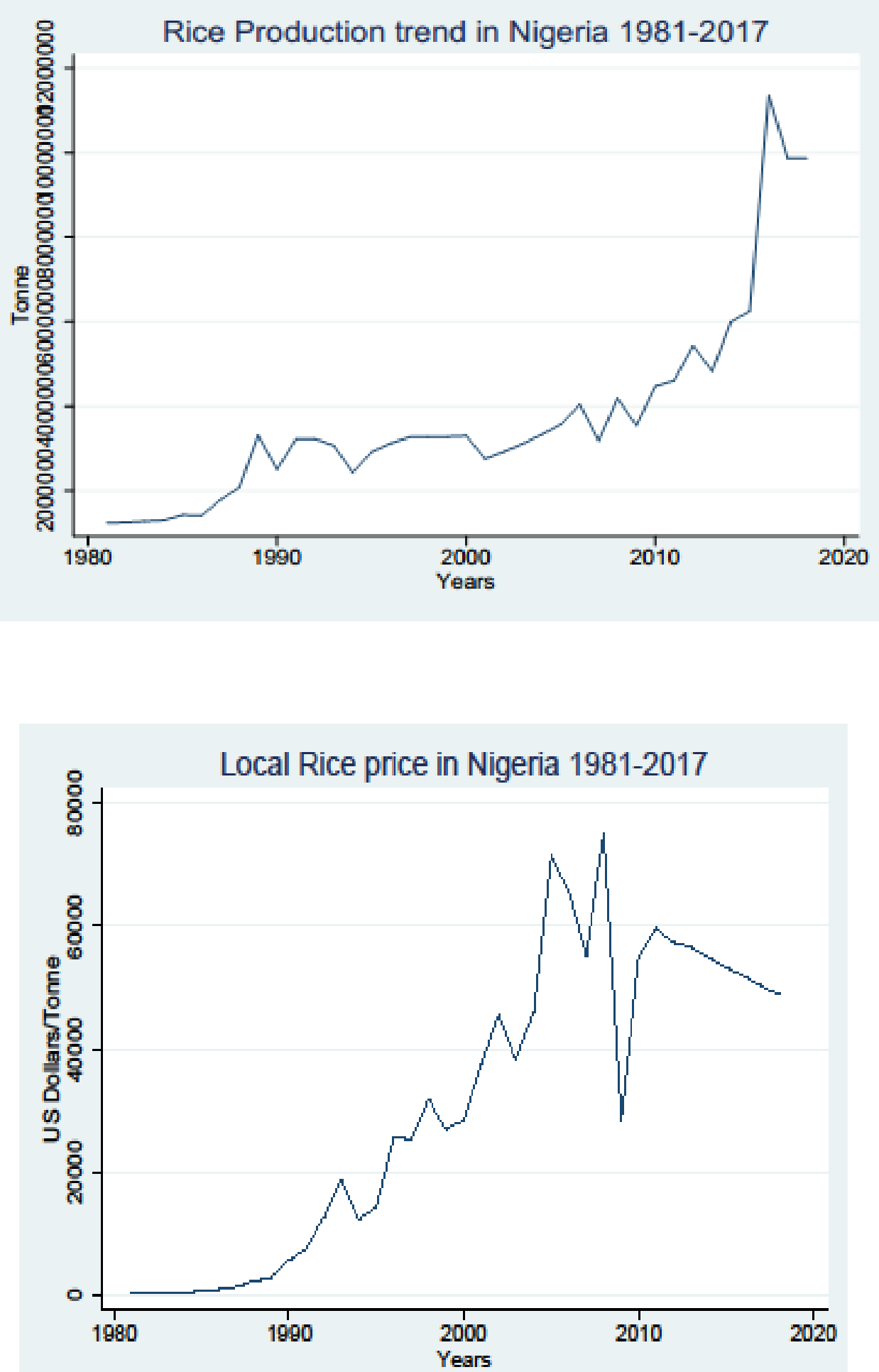
International Journal of Agriculture, Environment and Bioresearch

Vol. 5, No. 05; 2020

ISSN: $2456-8643$
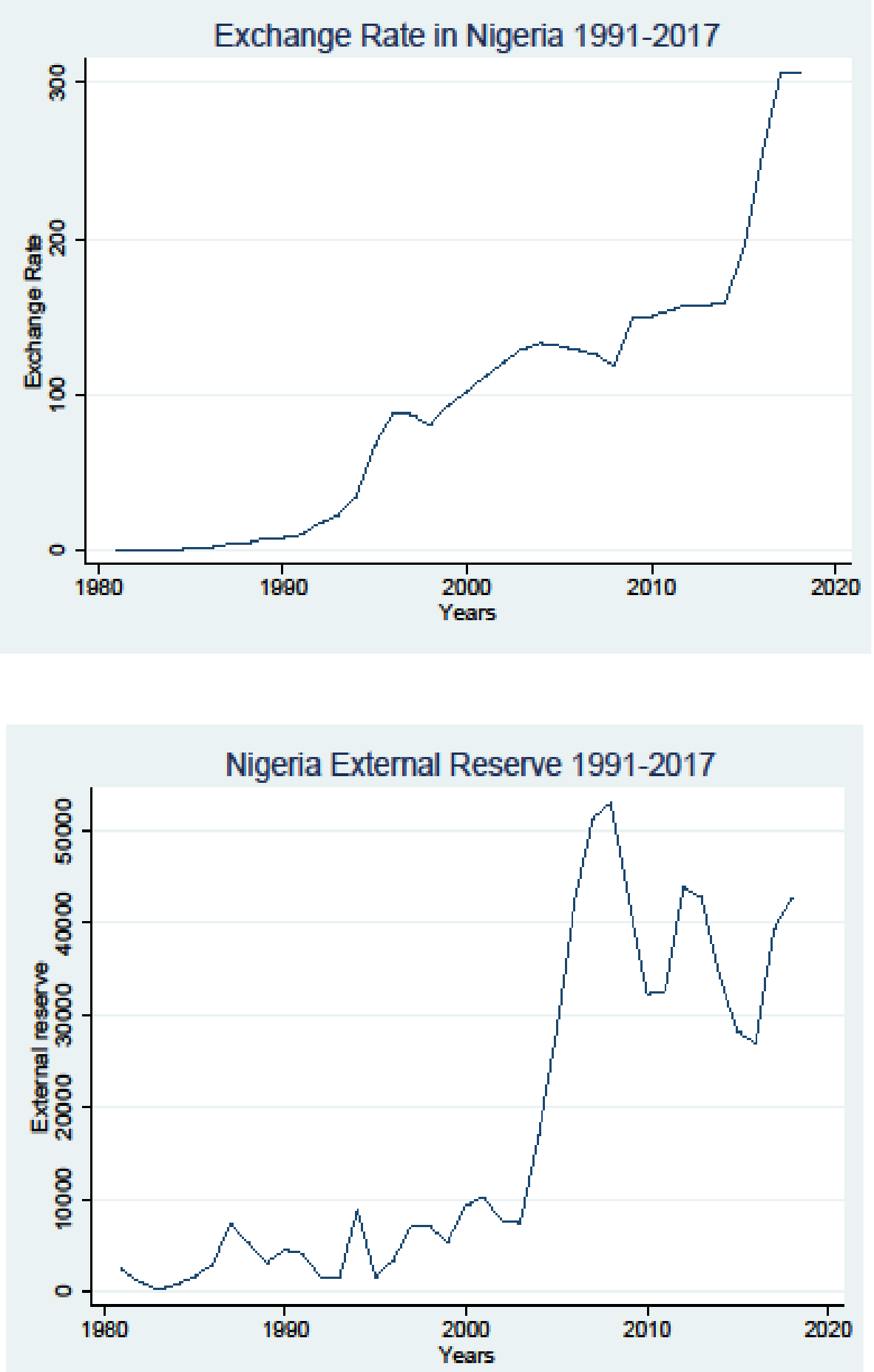


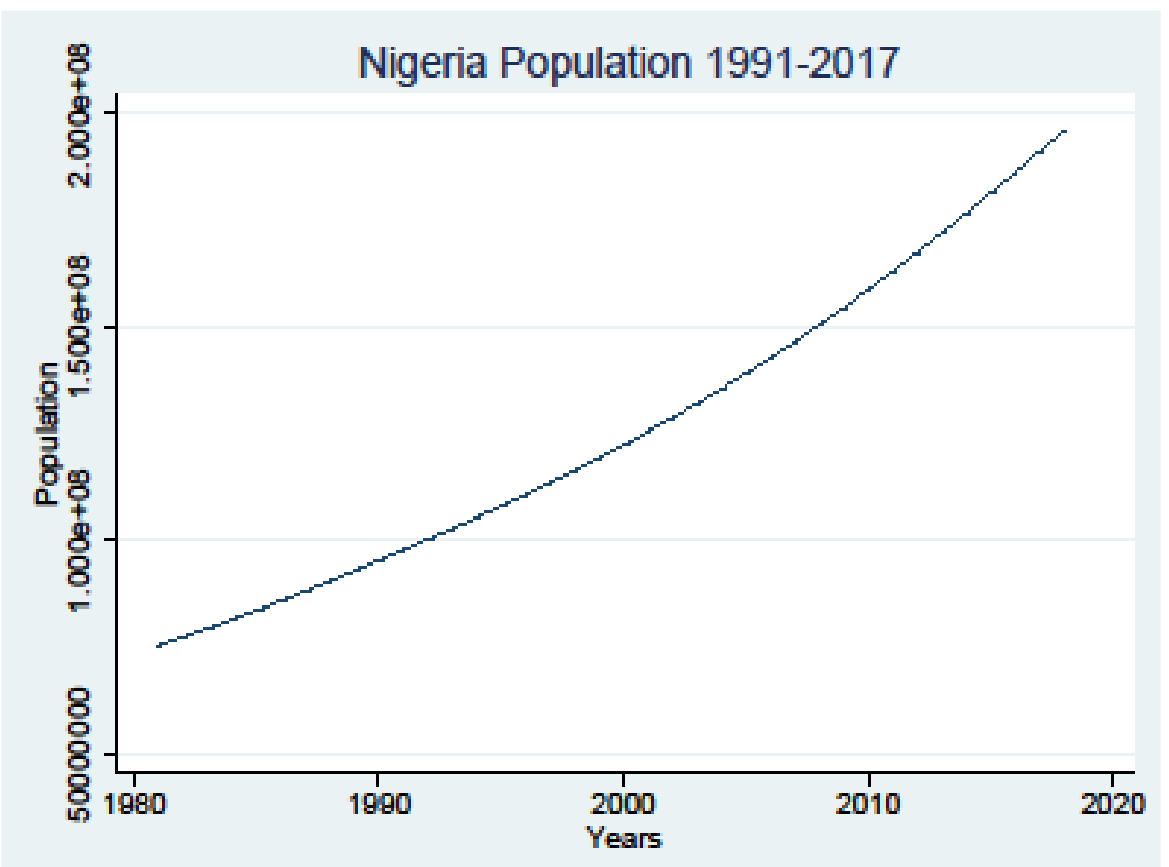

Table 1: Dickey Fuller Unit Root Test

\begin{tabular}{|l|l|c|l|}
\hline Variable & \multicolumn{1}{|c|}{ DF test } & Critical value at 5\% & \multicolumn{1}{|c|}{ Order of Integration } \\
\hline Rice prod & -3.146 & -2.966 & Significant and $1^{\text {st }}$ difference \\
\hline Rice import & -3.409 & -2.966 & Significant and $1^{\text {st }}$ difference \\
\hline Exchange rate & -2.993 & -2.966 & Significant and $1^{\text {st }}$ difference \\
\hline PLR & -3.630 & -2.966 & Significant and $1^{\text {st }}$ difference \\
\hline PFIR & -2.977 & -2.966 & Significant and $1^{\text {st }}$ difference \\
\hline Ex reserve & -3.693 & -2.966 & Significant and $1^{\text {st }}$ difference \\
\hline
\end{tabular}

Table 2: The Short-run ECM model Estimation

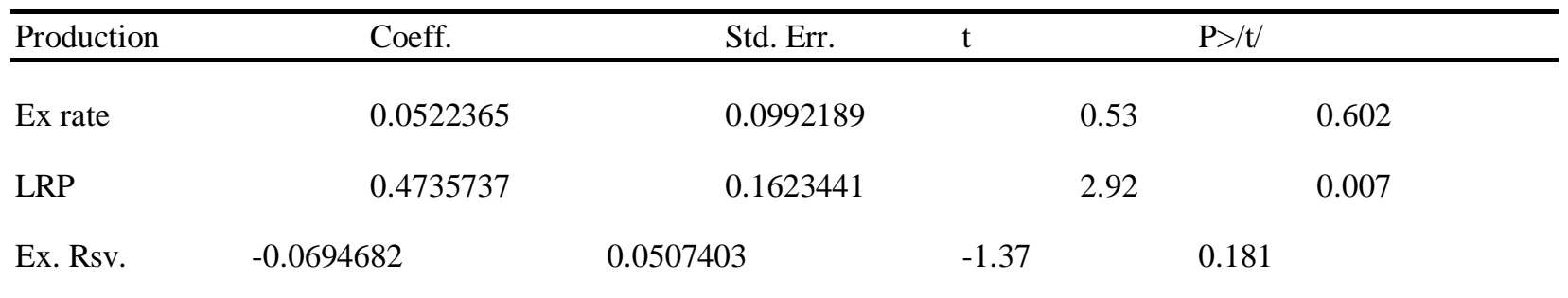




\begin{tabular}{lllll}
\hline POP & \multicolumn{1}{c}{3.17278} & 0.5692696 & 5.57 & 0.000 \\
N. GDP & -0.2031239 & 0.0705559 & -2.88 & 0.007 \\
Constant & -40.92233 & 9.867292 & -4.15 & 0.000 \\
Number of lags $=1$ & & & \\
\hline
\end{tabular}

Source: Authors Computation, 2019

Table 3: The Long-run ECM model Estimation

\begin{tabular}{lllll}
\hline D. Production & Coeff. & Std. Err. & $\mathrm{t}$ & \multicolumn{2}{c}{$\mathrm{P}>/ \mathrm{t} /$} \\
\hline Ex rate & 0.1695335 & 0.1217903 & 1.39 & 0.175 \\
LRP & 2.182777 & 1.137537 & 1.92 & 0.065 \\
Ex Rsv & 0.0037599 & 0.0386512 & 0.10 & 0.923 \\
Pop & 110.8079 & 43.27378 & 2.56 & 0.0116 \\
GDP & 0.0879866 & 0.0503728 & 1.75 & 0.092 \\
& $\quad$ Constant & -2.828546 & &
\end{tabular}

\section{SUMMARY}

Nigeria is an agro-based country and agriculture in Nigeria is a branch of the economy in the country, providing employment for many citizens. The sector is being transformed by commercialization at the small, medium and large-scale enterprise levels. Agricultural product in Nigeria is not sufficient and can't meet the demand of the people, many agricultural product are imported into the country to meet demand and exported out due to excess of supply. The main objectives of this paper was directed toward rice production in Nigeria using annual time series data from 1981-2017. Some econometric tools were employed to explore the relationship between the variable specified in the model. The study examines the characteristics of each time series correlation is absent, then we adopted the co-integration/ECM test methods to determine the long-run relationship between the independent variables.

The Dickey-Fuller test conducted on the variables showed that while population on rice production is stationary at levels, exchange rate, imported rice price, external reserve and gross domestic product were however stationary at first difference. The Engel Granger test makes fewer distribution assumptions and does not allow the identification of the number of cointegration vectors.

The result of the error correlation model showed that in the short run: Value of the Exchange rate Naira to US Dollars, Imported Rice Price and GDP and population exerted significant positive influence on rice production while Ex Rsv (External Reserve) and Ex rate (Exchange rate) failed to significantly explain the variation in rice production in Nigeria during the period under investigation. The study in the short run concludes that imported rice price is indispensable for 
adequate supply of rice in Nigeria which leads to the acceptance of alternative hypothesis and the rejection of the null hypothesis.

The results from the test indicate that there exists long run relationship between Ex rate, Ex Rsv and POP and on Imported rice when second step of Engel-Granger ECM estimation was analysed. Ex rate, Ex Rsv and POP coefficient are positively correlated with agricultural productivity at $1 \%$ level of significant and 1 lag lengths is found to granger while IRP (Imported Rice Price) and GDP (Gross Domestic Product) are not significant, having a negative repercussion on imported rice in Nigeria at this time trend resulting to rejection of alternative hypothesis and acceptance of null hypothesis. The study concludes that price of imported rice is not related to rice production in Nigeria.

\section{CONCLUSION}

The study concluded that IRP and GDP were not significant to rice production but other variables Ex rate, Ex Rsv and POP were significant to rice production in which IRP, Ex Rsv and POP has a positive relationship to rice production and Ex rate and GDP has a negative relationship to rice production in Nigeria.

\section{RECOMMENDATIONS}

Based on the findings, the following recommendations are therefore suggested in other to improve rice production in the country: Government should provide loan for rice farmer and purchase of rice processing equipment to improve production of rice.International donors should come to the aid of rice farmers in rural financing in the areas.Extension agents should educate the farmers adopting rice varieties such as upland, lowland and swamp production system on best practice for optional production and income maximization. The different agents in the inputsupply stage especially FMARD and ADP should be encouraged to provide inputs (e.g rice seeds, fertilizer, agro-chemicals etc) timely and make the inputs more accessible by farmers. The quality of local rice should be improved in order to increase the price competiveness of the local rice to those of the imported rice. This will encourage consumers to buy more of the local rice as the difference between the local and imported rice quantity would be negligible. This increase in demand of local rice will now serve as a boost towards increase rice production by the farmers with this increase the per capital income of the farmers will be raised.

\section{REFERENCES}

Boansi D (2014) Yield response of rice in Nigeria: A co-integration analysis. American Journal of Agriculture and Forestry, 2(2): 15-24

Chinaka, C.C, Ogbokiri, L.C. and Chinaka E.C. (2007), Adoption of Improved Agricultural Technologies by Farmers in Aba Agricultural Zone of AbiaState.Proceedings of the 41st conference of the Agricultural Society of Nigeria, IAR/ABU Zaria, Nigeria. pp. 531-534. Imolehin, E.D. and Wada, A.C. (2000), "Meeting Rice Production and Consumption Demand of Nigeria with improved Technologies", International Rice Commission Newsletters, Vol. 49, FAO, Rome.

Federal Ministry of Agriculture and Rural Development (FMARD), 2004.Ministerial Press Briefing by Minister of Agriculture and Rural Development on the State of Nigerian Agriculture at Maizube Farms.May 16, 2004, Niger State. 
Vol. 5, No. 05; 2020

ISSN: $2456-8643$

Federal Office of Statistics, Abuja, Nigeria. Trade Summary (Several issues) Federal Government of Nigeria, Annual Budgets, 1981 up till 2018

Federal Republic of Nigeria.Accelerated Rice Production in the Niger River Basin. http://enplan.org/tadashongarice.pdf 2006;accessed 19.10.2017.

Food and Agricultural Organization (FAO), 2000.Agriculture towards 2015/30 Technical Interim Report. April, 2000. Rome.

Food and Agricultural Organization (FAO), 2018.FAO Rice Conference 2001. Accessed Online at www.fao.org

Food and Agricultural Organization (FAO), 2019.FAO Rice Conference 2002. Accessed Online at www.fao.org

FAO, 2017 Nigeria at a glance www.fao.org/nigeria/fao-in-nigeria/nigeria-at-a-glance/en/.2017; accessed 22.03.2017.

Global Agricultural Information Network.Nigeria's grain and feed annual report.https://gain. fas.usda.gov/Recent\%20GAIN\%20Publications/Grain\%20and\%20Feed\%20Annual_Lagos_Nige ria_4- 21-2016. pdf. 2016;accessed 22.02.2017.

International Rice Research Institute (IRRI, 2017). International Rice Research Institute. Retrieved from http://www.irri.org.

International Rice Research Institute (IRRI, accessed Sep 2019). Milling and processing. IRRI Rice Knowledge Bank. www.knowledgebank.irri.org/step-by-step production

Live Rice Index (2019). USDA: Data for period 2010 to 2017. Live Rice Index, United Kingdom. www.livericeindex.com

National Bureau of Statistics, "Consumption pattern in Nigeria 2009/10," Preliminary Report, National Bureau of Statistics, 2012.

National Bureau of Statistics/ Federal Ministry of Agriculture and Rural Development (2012): Collaborative survey on National Agriculture Sample Survey (NASS) 2010/2011.

National Population Commission (NPC, 2006). Provisional of State and Local Government totals of the 2006 population census of the Federal Republic of Nigeria. Retrieved from http://www.nigerianstat.gov.ng

National rice development strategy.Prepared for the Coalition for African Rice Development. Pp. 62

NBS, 2007.National Agricultural Statistics Survey report, 1994/95 - 2005/06. National Bureau of Statistics, Abuja, Nigeria

NBS, 2011a.Agricultural Survey Report, 2006/07 - 2009/10. National Bureau of Statistics, Abuja,Nigeria

NBS, n.d. Nigeria data portal.Nigeria National Bureau of Statistics, Abuja, Nigeria. Available at http://nigeria.opendataforafrica.org/ (Accessed 29 December 2015)

Nigerian National Food Reserve Agency, Federal Ministry Of Agriculture and Water Resources \& Japan International Cooperation Agency (NFRA, FMA\&WR \& JICA) (2009)

Ogazi CG (2009) Rice output supply response to the changes in real prices in Nigeria: An autoregressive distributed lag model approach. Journal of Sustainable Development in Africa 11(4): 83-100 Retrieved from http://www.nigerianstat.gov.ng

World Bank, 2000. World Development Report 2000/2001: Attacking poverty, p. 275. Oxford University Press for World Bank, 